\title{
ZARZĄDZANIE KOMPETENCJAMI PRACOWNICZYMI W ASPEKCIE ROZWOJU ORGANIZACJI
}

\author{
Dorota Szmit \\ Politechnika Częstochowska \\ Wydział Zarządzania
}

\begin{abstract}
Streszczenie: Kompetencje pracownicze we współczesnej rzeczywistości w istotny sposób przyczyniają się do sukcesu organizacji. Dlatego w tekście przybliżono istotę kompetencji i ich oddziaływania na organizację. Podjęto próbę zidentyfikowania kompetencji pracowniczych, które w decydujący sposób określają rozwój i konkurencyjność organizacji oraz kształtują wizerunek firmy. Pokazano, że odpowiednie podejście do rozwoju kompetencji pracowniczych może skutkować jakością i efektywnością pracy. W podejściu kompetencyjnym punktem odniesienia jest pracownik zajmujący dane stanowisko, a nie samo stanowisko pracy.
\end{abstract}

Słowa kluczowe: kompetencje, zarządzanie kompetencjami, rozwój

DOI: $10.17512 /$ znpcz.2018.1.02

\section{Wprowadzenie}

Wiedza z zakresu kompetencji, ich podziałów oraz znaczeń na poszczególnych stanowiskach prowadzi do sukcesu, który odnoszą organy zarządcze tejże organizacji. System zarządzania przedsiębiorstwem musi na bieżąco monitorować zmiany, które zachodzą w otoczeniu, i dostosowywać je do potrzeb rynkowych (Pachura, Nitkiewicz, Kuraś 2016, s. 29-39). Dlatego skuteczne i efektywne działania pracowników coraz częściej łączone są z pojęciem kompetencji (Robbins, DeCenzo 2002, s. 263-265). Według M. Armstronga: „Zarządzanie zasobami ludzkimi oparte na kompetencjach polega na zastosowaniu pojęcia kompetencji i wyników analizy kompetencji w celach informacyjnych oraz w celu udoskonalenia procesów rekrutacji i selekcji, rozwoju i wynagrodzenia pracowników" (Armstrong 2002, s. 249).

W literaturze przedmiotu z zakresu zarządzania organizacją dotyczącej zarządzania zasobami ludzkimi coraz częściej pojawia się tematyka zarządzania kompetencjami. Jest ona wieloaspektowa i złożona w wymiarach taktycznym, operacyjnym czy strategicznym (Griffin 2017).

„Kluczowe kompetencje na ogół prowadzą do powstawania strategicznych zdolności firmy (strategic capabilities), a więc tych zasobów, procesów, kompetencji i umiejętności, które firma opanowała w najwyższym stopniu i które przyczyniają się do jej sukcesu rynkowego)" (Johnson, Scholes 1999, s. 149-150). „Istotna część kluczowych kompetencji organizacji powstaje na bazie rdzennych zasobów kadrowych, jakimi w dużym stopniu są kompetencje pojedynczych pracowników i zespołów" (por.: Gratton, Ghoshal 2003, s. 20-25). 
Celem artykułu jest analiza literatury przedmiotu, która ma ukazać wpływ kompetencji pracowniczych na rozwój organizacji.

\section{Typologia kompetencji pracowniczych}

Pojęcie kompetencji zostało po raz pierwszy użyte przez amerykańskiego psychologa społecznego Davida McClellanda na przełomie 60. i 70. lat XX wieku. Zaproponował on badanie cech, które nazwał kompetencjami, w miejsce badania cech osobowościowych.

Kompetencje nie są cechami stałymi. Zmieniają się wraz z doświadczeniem oraz rozwojem zawodowym i życiowym człowieka. Nie ma jednej zamkniętej listy kompetencji. Specjaliści cały czas tworzą różne ich zestawy. Kompetencje można szeregować w różny sposób, np. T. Rostowski proponuje osiem kategorii (Rostowski 2002):

1. Kompetencje związane z uzdolnieniami. Odnoszą się do potencjału pracownika, możliwości rozwoju, wykorzystania uzdolnień w celu zdobycia nowych kompetencji. Ich znaczenie jest tym większe, im bardziej przedsiębiorstwo nastawione jest na zmiany i konieczność rozwoju „nowych kompetencji”.

2. Kompetencje związane z umiejętnościami i zdolnościami. Dotyczą czynników niezbędnych dla odniesienia sukcesu w konkretnym zadaniu w pracy. Należą tu dobrze znane od dawna kompetencje komunikacyjne, umysłowe, interpersonalne, organizacyjne, techniczne, biznesowe, przywódcze itp.

3. Kompetencje związane $\mathrm{z}$ wiedzą. To przygotowanie do wykonywania konkrenych zadań w ramach zawodu, specjalizacji, stanowiska czy organizacji. W tej kategorii mieszczą się kompetencje, które opisują to, czego pracownik nauczył się do tej pory i co może zastosować w odpowiedniej sytuacji. Wiedza może dotyczyć faktów, wydarzeń, procedur, teorii.

4. Kompetencje fizyczne. Dotyczą umiejętności związanych $\mathrm{z}$ fizycznymi wymaganiami stanowiska pracy. Dzielą się na trzy grupy:

a) sprawność fizyczna,

b) wyczulenie zmysłów,

c) zdolności psychofizyczne.

5. Kompetencje związane ze stylami działania. Opisują, w jaki sposób określane są cele, jaka jest umiejętność planowania i zdolności organizacyjne; jaka jest zdolność wizualizacji ciągu działań oraz ustalania, jakie zasoby są potrzebne do osiągania celu; jaka jest umiejętność działania w sposób dokładny i uporządkowany.

6. Kompetencje związane z osobowością. Przez kompetencje osobowościowe (społeczne) rozumiemy złożone umiejętności warunkujące efektywność radzenia sobie w określonego typu sytuacjach społecznych. Kompetencje te wypływają z cech osobowości, mają bezpośredni wpływ na jakość i sposób wykonywania powierzonych zadań, decydują o właściwym funkcjonowaniu w grupie, budowaniu odpowiednich relacji z innymi ludźmi. Kompetencje osobowościowe to umiejętności zapewniające skuteczność realizacji celów w sytuacjach społecznych, czyli podczas kontaktów z innymi ludźmi. Dzięki nim jesteśmy 
w stanie wykorzystać w pełni nasz potencjał kwalifikacyjny, specjalistyczną wiedzę i zawodowe doświadczenie.

7. Kompetencje związane z zasadami i wartościami. Dotyczą zasad, wartości, wierzeń, pozwalają na określenie motywów działania. Odnoszą się do tego, czego poszukuje się w pracy, oraz do ról życiowych, które wpływają na dokonywane wybory.

8. Kompetencje związane z zainteresowaniami. Oznaczają preferencje dotyczące zadań i rodzaju pracy oraz środowiska pracy. Mają wpływ na efektywność, zwłaszcza wtedy, kiedy rodzaj pracy jest w pełni zgodny $\mathrm{z}$ rodzajem zainteresowań pozazawodowych.

M. Armstrong napisał: „Kompetencja implikuje zdolność przeniesienia tego, co ludzie wiedzą i rozumieją, do różnych kontekstów, tj. różnych aspektów pracy" (Armstrong 2002, s. 244).

R. Boyatzis, biorąc pod uwagę poziom i zakres wymaganych kompetencji, wyróżnił (Boyatzis 2008):

Kompetencje progowe (treshold competencies) - są to podstawowe kompetencje wymagane na danym stanowisku. Nie rozróżniają osób, które osiągają dobre lub gorsze rezultaty pracy.

Kompetencje kluczowe - to te, które odzwierciedlają, co dana organizacja potrafi robić najlepiej.

Kompetencje optymalne - prowadzą do osiągania pożądanych, optymalnych w określonych warunkach wyników.

Inny podział funkcjonalny kompetencji proponuje G. Filipowicz, który wyróżnia (Filipowicz 2004):

1. Kompetencje osobiste - związane z indywidualną realizacją zadań. Poziom tych kompetencji wpływa na ogólną jakość wykonywanych zadań - decyduje o szybkości, adekwatności i rzetelności podejmowanych zadań, jak na przykład:

$$
\begin{aligned}
& \text { dążenie do rezultatów, } \\
& \text { elastyczność myślenia, }
\end{aligned}
$$$$
\text { gotowość do uczenia się, }
$$$$
\text { kreatywność, }
$$

myślenie analityczne,

organizacja pracy własnej,

otwartość na zmiany,

podejmowanie decyzji,

radzenie sobie ze stresem,

rozwiązywanie problemów,

rozwój zawodowy,

sumienność,

samodzielność,

zarządzanie czasem.

2. Kompetencje społeczne - wpływają na jakość wykonywanych zadań związanych $\mathrm{z}$ kontaktem $\mathrm{z}$ innymi ludźmi. Poziom tych kompetencji decyduje o skuteczności współpracy, porozumiewania się czy też wywierania wpływu na 
innych. Należą do nich np.:

- autoprezentacja,

- budowanie relacji z innymi,

- dzielenie się wiedzą, doświadczeniem,

- identyfikacja z firmą,

- komunikacja pisemna,

- komunikatywność,

- kultura osobista,

- negocjowanie,

- obycie międzykulturowe,

- współpraca w zespole,

- relacje z przełożonymi.

3. Kompetencje menedżerskie - związane są $\mathrm{z}$ zarządzaniem pracownikami. Dotyczą zarówno miękkich obszarów kierowania, organizacji pracy, jak również strategicznych aspektów zarządzania. Poziom tych kompetencji decyduje o sprawności funkcjonowania podległego obszaru. Należą do nich np.:

- budowanie sprawnej organizacji,

- budowanie zespołów,

- coaching,

- delegowanie zadań,

- kierowanie,

- kontrola menedżerska,

- motywowanie,

- myślenie strategiczne,

- ocena i rozwój podwładnych,

- odwaga kierownicza,

- organizowanie,

- planowanie,

- przywództwo,

- rozwiązywanie konfliktów.

4. Kompetencje specjalistyczno-techniczne - te kompetencje mają związek ze specjalistycznymi zadaniami dla danej grupy stanowisk. Poziom tych kompetencji wpływa na efektywność realizacji zadań związanych ze specyfiką zawodu, stanowiska bądź też funkcji. Należą do nich:

- analiza danych,

- analiza pracy,

- analiza rynku,

- budżetowanie,

- diagnozowanie potrzeb klienta,

- dyspozycyjność,

- ewaluacja projektów,

- inżynieria finansowa,

- języki obce, 
- księgowość,

- planowanie i organizowanie szkoleń,

- rekrutacja i selekcja,

- rozliczanie i administrowanie wynagrodzeniami,

- prowadzenie szkoleń.

\section{Podejście miękkie i twarde w klasyfikowaniu kompetencji pracowniczych}

W literaturze przedmiotu spotykamy pojęcia kompetencji miękkich, rozumianych jako umiejętności osobiste, społeczne, interpersonalne, komunikacyjne, oraz kompetencji twardych, rozumianych jako cechy konkretne, mierzalne, niezbędne do wykonywania danej pracy. Elementy składowe przynależne kompetencjom miękkim i twardym zostały graficznie zaprezentowane na Rysunku 1 i Rysunku 2. Ich analiza wykazuje wyraźną odrębność jednych i drugich.

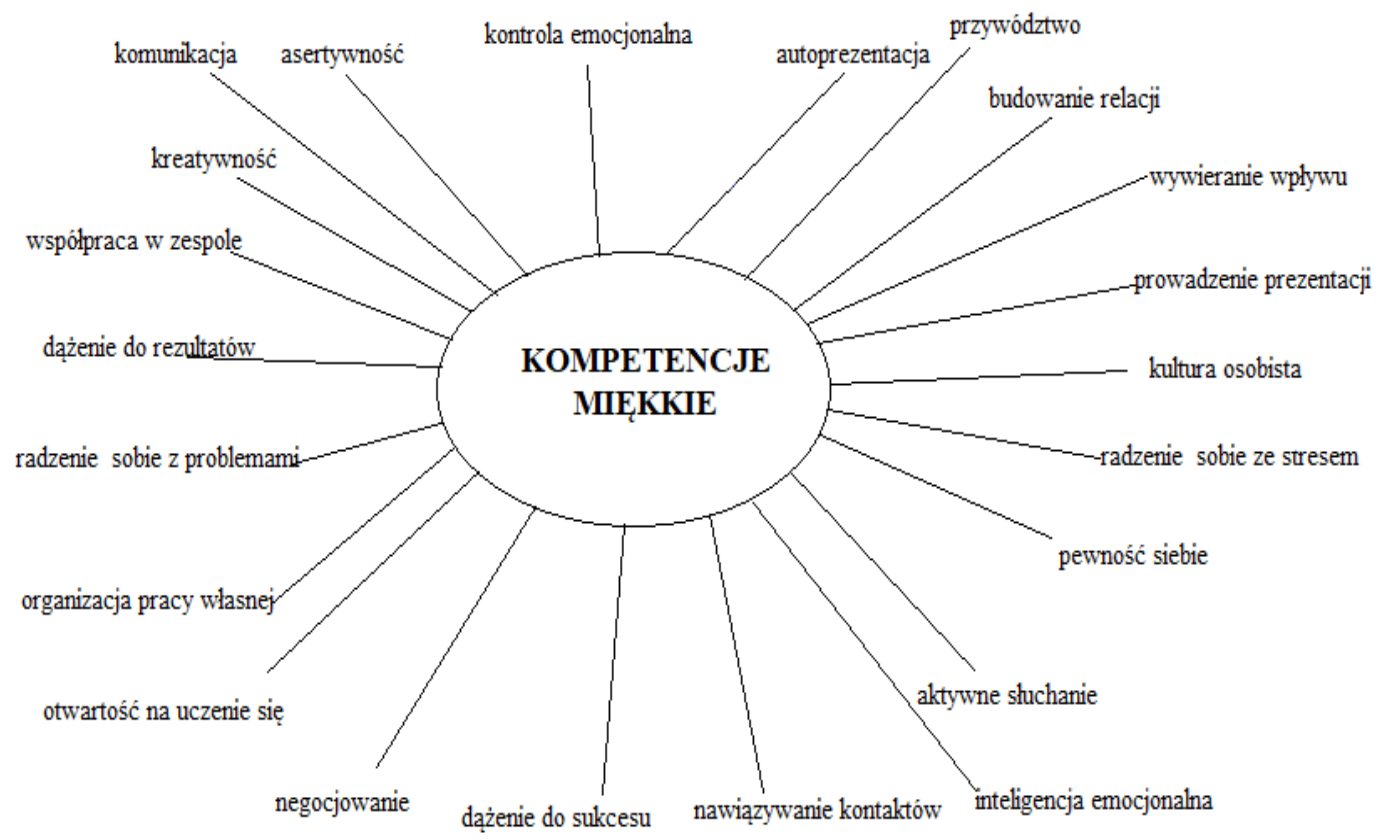

Rysunek 1. Komponenty miękkich kompetencji pracowniczych

Źródło: Opracowanie własne

Kompetencje miękkie to suma umiejętności komunikacyjnych (np. empatia), emocjonalnych (np. współodczuwanie) i społecznych (np. taktowność), które w zdecydowany sposób odpowiadają za stosunki międzyludzkie. Kompetencje miękkie skupiają się na sposobie zachowania danej osoby w zależności od kontekstu sytuacyjnego. 


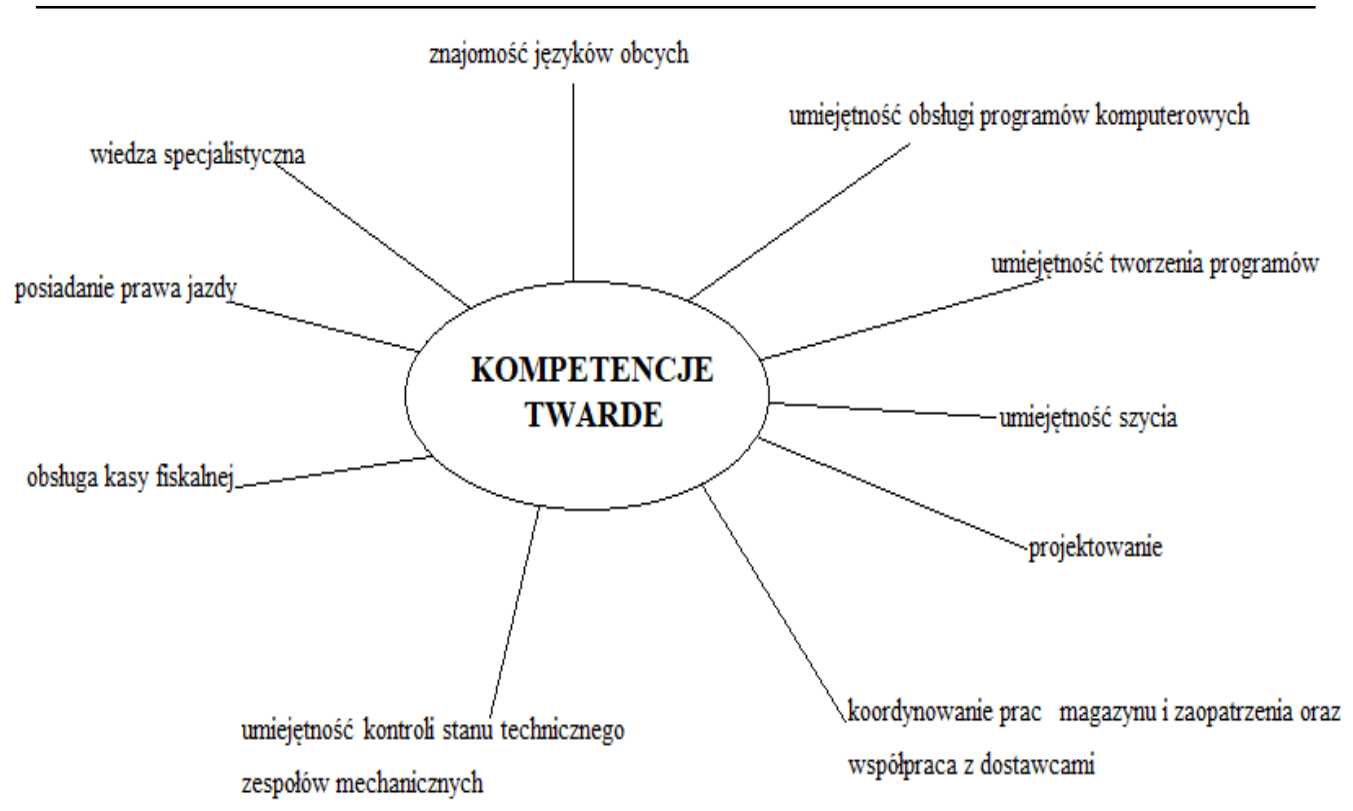

Rysunek 2. Komponenty twardych kompetencji pracowniczych

Źródło: Opracowanie własne

Kompetencje behawioralne rozpatrywane są także jako potencjał, który można rozwijać i doskonalić oraz dzięki któremu można nabywać kolejne nowe kompetencje (Kubicka-Daab 2001). Na kompetencje miękkie można spojrzeć w trzech różnych aspektach. Zostały one przedstawione w Tabeli 1.

Tabela 1. Aspekty kompetencji miękkich

\begin{tabular}{|c|c|c|}
\hline Aspekt & Charakterystyka & Sposób pomiaru \\
\hline poznawczy & $\begin{array}{c}\text { umiejętność trafnego myślenia o sytuacjach } \\
\text { społecznych, empatia poznawcza, znajomość } \\
\text { reguł społecznych, umiejętność planowania } \\
\text { zachowań społecznych }\end{array}$ & $\begin{array}{c}\text { testy inteligencji } \\
\text { społecznej, } \\
\text { kwestionariusze } \\
\text { inteligencji emocjonalnej, } \\
\text { strukturyzowane wywiady }\end{array}$ \\
\hline motywacyjny & $\begin{array}{l}\text { tendencja do podejmowania ryzyka } \\
\text { społecznego oraz angażowania się w sytuacje } \\
\text { społeczne }\end{array}$ & $\begin{array}{l}\text { kwestionariusze pewnych } \\
\text { cech osobowości } \\
\text { i temperamentu, które } \\
\text { wiążą się z inicjatywą } \\
\text { w kontaktach } \\
\text { międzyludzkich oraz } \\
\text { towarzyskich }\end{array}$ \\
\hline motoryczny & $\begin{array}{l}\text { posiadane i wykorzystywane umiejętności } \\
\text { społeczne }\end{array}$ & $\begin{array}{c}\text { szacowanie, obserwacja, } \\
\text { ustrukturyzowane } \\
\text { w naturalnym środowisku } \\
\text { techniki symulacyjne }\end{array}$ \\
\hline
\end{tabular}

Źródło: (http://pwszzamosc.pl/...) 
Kompetencje twarde bardzo często określane są mianem bazowych, podstawowych, bez których nie ma możliwości brania udziału w rekrutacji na określone stanowisko. Są to cechy konkretne i mierzalne, które można potwierdzić dyplomami, certyfikatami, świadectwami lub podczas kolejnych etapów procesu rekrutacyjnego. W tej grupie kompetencji znajduje się posiadana wiedza oraz umiejętności. Cechy te możemy rozwijać, a uzależnione są od tego, jaki zawód zamierzamy wykonywać bądź wykonujemy. Kompetencje twarde odnoszą się do progowych wymagań dotyczących określonego stanowiska (roli zawodowej) (Whiddett, Hollyforde 2003).

\section{Wpływ kompetencji pracowniczych na rozwój organizacji}

Teoretycy i praktycy zarządzania są zgodni, że kluczowym zasobem każdej współczesnej organizacji, silnie oddziałującym na możliwości jej rozwoju, jest kapitał ludzki. „Kapitał ludzki to przede wszystkim kompetencje pracowników, wynikające $\mathrm{z}$ ich wiedzy, doświadczenia i predyspozycji intelektualnych, umiejętności praktycznego zastosowania wiedzy i wykorzystania posiadanych talentów na potrzeby przedsiębiorstwa, to również chęć pełnego zaangażowania się w wykonywane na rzecz przedsiębiorstwa działania, postawy i motywacja zatrudnionych" (Ziółkowska 2013, s. 133). Poziom kompetencji pracowniczych zależy od posiadanej wiedzy, na którą składają się kwalifikacje i doświadczenie zawodowe, umiejętność ich wykorzystania, cechy osobowościowe, indywidualne zdolności oraz sama postawa i motywacja (Rogozińska-Pawełczyk 2006, s. 108).

Każda osoba przyjmująca się do organizacji próbuje wykazać swoje kompetencje, natomiast organizacja próbuje oszacować, na ile te kompetencje są przydatne organizacji. Jednocześnie określane są predyspozycje do rozwoju kompetencji, które w przyszłości mogą pomóc w sukcesie organizacji.

Na poziom kompetencji mają wpływ czynniki zarówno zewnętrzne, jak również wewnętrzne.

Tabela 2. Determinanty poziomu kompetencji w organizacji

\begin{tabular}{|c|c|}
\hline Czynniki wewnętrzne & Czynniki zewnętrzne \\
\hline $\begin{array}{c}\text { posiadana wiedza } \\
\text { umiejętności } \\
\text { zdolności } \\
\text { osobowość } \\
\text { percepcja } \\
\text { potencjał intelektualny } \\
\text { system wyznawanych norm i wartości } \\
\text { przekonania } \\
\text { zasady etyczno-moralne } \\
\text { przyjmowane postawy } \\
\text { poziom motywacji }\end{array}$ & $\begin{array}{l}\text { przekazywana wiedza } \\
\text { style działania } \\
\text { otoczenie zewnętrzne } \\
\text { przekazywane postawy } \\
\text { motywowanie } \\
\text { wzorce zachowań }\end{array}$ \\
\hline
\end{tabular}

Źródło: Opracowania własne 
Dla wyżej wymienionych czynników najważniejszymi komponentami kompetencji są wiedza i umiejętności.

Wiedza - zarówno ogólna, jak specjalistyczna, zdobyta lub w trakcie zdobywania jest określeniem statusu wykształcenia i można ją potwierdzić dyplomami, świadectwami bądź certyfikatami. Najczęściej utożsamiana jest z kwalifikacjami.

Umiejętności - cechy, które predysponują do wykonywania określonych zadań. Posiadane umiejętności najczęściej utożsamiane są z doświadczeniem.

Postawy - decydują o wykorzystaniu odpowiednio wiedzy i umiejętności. Jest to cecha, która uruchamia mechanizmy odpowiedzialne za rozpoczęcie, ukierunkowanie i podtrzymanie działań.

Kompetencje nie są cechami stałymi. Zmieniają się wraz z doświadczeniem, rozwojem zawodowym i życiowym człowieka. Kompetencje bywają czynnikiem kluczowym sukcesu dla danej organizacji. Wpływają na ocenę organizacji pod różnymi względami: organizacyjnym, społecznym czy ekonomicznym (Mintzberg 2013). Są one zbiorami osobistych zasobów pracownika. Jest to też cecha ukryta, która uwidacznia się $\mathrm{w}$ organizacji $\mathrm{w}$ określonych zachowaniach ludzi. Znaczenie kompetencji ujawnia się przede wszystkim $\mathrm{w}$ organizacji, która jest zainteresowana konkretnymi korzyściami wynikającymi z kompetencji osób pracujących na rzecz organizacji. Przedsiębiorstwo inteligentne przeciwdziała stagnacji, tworzy klimat sprzyjający twórczemu uczeniu się i kreowaniu innowacji, a także rozwijaniu przedsiębiorczości wewnętrznej, która oznacza inicjowanie i rozwijanie nowych zamierzeń wewnątrz organizacji. Zarządzanie kompetencjami doskonale wpisuje się w nurt tych zmian. Wymieniane jest jako jedna z nowoczesnych koncepcji epoki „drugiej rewolucji menedżerskiej” (Kuc, Paszkowski 2007, s. 24). Szybkie zmiany na rynku wymuszają budowanie strategii organizacji, która opiera się na kluczowych kompetencjach pracowników. Zadaniem kompetencji pracowniczych jest realizacja określonych zadań zawodowych. Podejście kompetencyjne proponuje powstawanie modeli bazujących na mierzeniu poprzez zobiektywizowane procedury, instrukcje bądź metody właściwości osób podczas selekcji, ale również $\mathrm{w}$ trakcie pracy, podczas motywowania do rozwoju czy wreszcie na ocenianiu.

Dzięki odpowiednio opisanym profilom kompetencyjnym można oczekiwać, iż osoba zatrudniona na danym stanowisku $\mathrm{z}$ dużym prawdopodobieństwem będzie potrafiła swobodnie wykonywać szeroki wachlarz zadań. Stworzenie schematu kluczowych kompetencji stanowi podstawę do tworzenia programów, które mają pomóc $\mathrm{w}$ rozwoju personelu, a w dalszej kolejności pozwolić organizacji osiągnąć oczekiwany sukces. Dobór metod zależy od prawidłowego scharakteryzowania jednostki i zadań, jakie ma realizować. Metody, które rozwijają kompetencje, promują aktywne działanie poprzez rozwiązywanie realnych problemów organizacji, okazują się najskuteczniejsze. Tutaj duże zadania stawiane są przed osobami odpowiedzialnymi za budowanie określonej strategii konkurencyjnej na rynku.

Jednocześnie można wskazać szereg kompetencji menedżerskich, które często bywają decydujące dla osiągnięcia wyznaczonego poziomu rozwoju organizacji (Krawczyk-Sokołowska 2008, s. 153). Budując własny system zarządzania kompetencjami dostosowany do strategii konkretnej organizacji, menedżerowie personalni mają pewność, że będzie on wspierał jej rozwój i ukierunkowywał rozwój pra- 
cowników w sposób określony przez strategię. Każda organizacja dąży do wzmocnienia i postępu, stara się jak najlepiej realizować efektywnie własne cele. Poprzez zaplanowanie swych działań i jak najlepsze wykorzystanie posiadanych zasobów stara się dobrze spełniać swoje funkcje społeczne. Otoczenie, w którym działa, zarówno ogranicza, jak i zmusza ją do poszukiwania nowych, lepszych rozwiązań, efektywniejszego zastosowania czynników wytwórczych dla unikania zagrożeń, ale również do wykorzystania pojawiających się szans i możliwości (Penc 2007, s. 8).

„Zarządzanie kompetencjami zawodowymi jest takim sposobem prowadzenia polityki personalnej w firmie, w przypadku którego pojęcie kompetencji staje się ogniwem łączącym działania z różnych zakresów (rekrutacja i selekcja, ścieżki kariery i następstw, oceny pracowników, szkolenia, systemy motywacyjne itp.). Inaczej mówiąc, jest to budowanie wspólnych relacji, pozwalających na tworzenie jednolitej płaszczyzny działań w ramach zarządzania zasobami ludzkimi. Natomiast podstawowym celem wdrażania zarządzania kompetencjami zawodowymi w firmie jest zagwarantowanie odpowiednich zasobów kompetencji, niezbędnych do osiągnięcia strategicznych celów organizacji” (Filipowicz 2004, s. 46-48).

$\mathrm{W}$ innowacyjnych przedsiębiorstwach od specjalistów oczekuje się, że będą umieli ocenić możliwości i potencjał kompetencji, który tkwi w posiadanych zasobach ludzkich organizacji (Krawczyk-Sokołowska 2012). Zwłaszcza kierownicy są zobowiązani do wykazania się szczególnymi kompetencjami w zakresie sprawności i skuteczności w podejmowaniu decyzji (Skowron-Grabowska i in. 2016, s. 82). Ważnym elementem tworzenia strategii rozwoju przedsiębiorstwa jest wybór źródła pozyskiwania strategicznego źródła kluczowych zasobów (Seroka-Stolka 2017, s. 30). Każda organizacja, której celem jest rozwój, po przeprowadzeniu analizy swoich możliwości i ryzyka, stwierdza, że najcenniejszym jej zasobem są ludzie, jej kapitał intelektualny i kompetencje pracownicze (Skowron-Grabowska 2015). Przedsiębiorstwo, dążąc do sukcesu, podporządkowuje działania, które są realizowane przez pracowników. Jednocześnie działania te wynikają z uprawnień posiadanych przez pracowników i odpowiedniego umiejscowienia ich w strukturze organizacji. Jasne określenie kompetencji w firmie przynosi wiele korzyści. Dobrze zdefiniowane kompetencje mówią pracownikowi, które zachowania są postrzegane przez pracodawcę jako przynoszące sukces na stanowisku. Świadome i profesjonalne wykorzystanie modeli kompetencji w firmach pozwala na rzetelne zarządzanie sukcesją (https://hrwisdomkeeper.wordpress.com/...).

Właściwie zarządzane kompetencje potrafią zdeterminować sukces organizacji. W związku z tym organizacja powinna umieć odpowiedzieć na pytania:

Czy prawidłowo wykorzystywany jest potencjał pracowników?

Czy pracownicy znają oczekiwania organizacji wobec nich?

Czy organizacja zna kompetencje, które będą pożądane w przyszłości?

Czy organizacja uzupełnia „luki kompetencyjne”? (np. prowadzi doskonalenie kompetencji).

Zarządzanie kompetencjami w organizacji jest wysoko kwalifikowaną działalnością odnoszącą się do pracowników i kadry zarządzającej firmą nie mającej statusu pracowników. Celem owej działalności jest zapewnienie wysokich standardów pracy, rozwój i alokacja kapitału ludzkiego organizacji w zakresie umożliwia- 
jącym jej przetrwanie i postęp oraz zakładanie osiąganych celów. Zarządzanie kompetencjami obejmuje planowanie i organizowanie stosownych działań, inspirowanie i motywowanie ludzi w kierunku doskonalenia zawodowego i podejmowania się nowych bądź szerszych ról organizacyjnych oraz kontrolę przebiegu związanych z powyższym procesów (Oleksyn 1999, s. 63).

Badania porównawcze korporacji efektywnych i nieefektywnych wykazały ponadto, że cenne kompetencje to (Bratnicki 2000, s. 24):

Bardziej zbiory umiejętności i wiedzy niż produktów i funkcji. Kompetencje leżące u podstaw dającej się utrzymać przewagi konkurencyjnej mają w znacznej mierze charakter intelektualny i są związane z systemami zarządzania, dotyczą one całości przedsiębiorstwa, czyli są interfunkcyjne.

Elastyczne, długotrwałe podłoże podlegające ewolucji ukierunkowanej tak, aby posiadać umiejętności w obszarach ważnych dla klienta.

Ograniczona liczba działalności umiejscowionych w elementach łańcucha wartości dodanej najbardziej krytycznych dla uzyskania powodzenia. Każda kompetencja wymaga intensywnego zarządzania, a więc rozproszenie uwagi kierownictwa na inne elementy grozi spadkiem efektywności.

Unikalne źródła rozwoju tkwiące w łańcuchu wartości dodanej. Efektywne strategicznie przedsiębiorstwa wyszukują miejsca, gdzie rynek wykazuje słabość albo gdzie pojawiają się luki wiedzy, które dane przedsiębiorstwo jest w stanie wypełnić, inwestując w zasoby intelektualne.

Dotyczą obszarów, w których przedsiębiorstwo może uzyskać pozycję dominującą. Firma uzyskuje ponadprzeciętną rentowność tylko wtedy, gdy potrafi realizować pewne, ważne dla klientów działania efektywniej od jakiegokolwiek innego podmiotu. Stąd też kompetencje wybrane jako ważne strategicznie należy budować aż do momentu, w którym jest się najlepszym w gronie potencjalnych dostawców niekoniecznie związanych z danym sektorem.

Elementy ważne dla klientów w długim okresie. Utrzymanie kompetencji wymaga ich zakotwiczenia w kulturze organizacyjnej oraz wszczepienia w strukturę organizacyjną i systemy działania.

Komponenty kompetencji organizacji determinowane są przez cel, który przedsiębiorstwo próbuje osiągnąć. Podczas tworzenia szczegółowych kompetencji w organizacji można wykorzystać podejścia takie jak:

1. kompetencje jako zmienne wpływające na wykonanie zadań zawodowych,

2. kompetencje jako charakterystyka pracownika efektywnego,

3. kompetencje jako suma indywidualnych kompetencji pracowników

i kompetencji organizacyjnych (Jabłońska-Wołoszyn 2003, s. 13).

\section{Podsumowanie}

W artykule wykazano, że kompetencje pracownicze mają bardzo duży wpływ na funkcjonowanie i rozwój organizacji. Niezależnie od rodzaju czy ilości kompetencji pracowniczych każda organizacja, chcąc efektywnie działać, powinna opracować swój schemat kompetencji. To właśnie te schematy powinny być doskonalone i wyróżniać przedsiębiorstwo na tle innych. Jednocześnie należy pamiętać, że 
kształtowanie nieodpowiednich kompetencji dla firmy bądź niezidentyfikowanie w odpowiednim czasie luki kompetencyjnej może doprowadzić do porażki organizacji. Ważne jest, aby tworząc model kompetencji danej organizacji, móc porównać teorię z efektami pracy pracowników i to wszystko zestawić z działalnością innych przedsiębiorstw. Teoretycznie kompetencje ukazują nam się jako pojęcie bardzo złożone. Praktycznie są narzędziem, dzięki któremu organizacja realizuje skutecznie strategię rozwoju. Dlatego kompetencje pracownicze w dominujący sposób mogą wpływać na konkurencyjność organizacji. Ustalając profil kompetencji, dajemy możliwość konkretnych działań rozwojowych, które mogą przyczynić się do sukcesu organizacji. Reasumując, problem kompetencji pracowniczych jest kwestią otwartą, która może być rozwijana zarówno przez praktyków, jak i teoretyków zarządzania zasobami ludzkimi i wymaga pogłębionych badań.

\section{Literatura}

Armstrong M. (2002), Zarządzanie zasobami ludzkimi, Oficyna Ekonomiczna, Kraków.

Blanchard K. (2010), Leading at a Higher Level. Blanchard on Leadership and Creating High Performing Organizations, FT Press, New Jersey.

1. Boyatzis R.E. (2008), Competencies in the 21st Century, ,Journal of Management 2. Development", Vol. 27, No. 1, s. 5-12. DOI: 10.1108/02621710810840730

3. Bratnicki M. (2000), Kompetencje przedsiębiorstwa, Agencja Wydawnicza Placet, Warszawa.

4. Denison D., Hooiberg R., Lane N. (2012), Leading Culture Change in Global Organizations. Aligning Culture and Strategy, Jossey-Boos, San Francisco.

Edgar W.B., Lockwood C.A. (2008), Organizational Competencies: Clarifying the Construct, ,Journal of Business Inquiry”, Vol. 7, No. 1, s. 21-32.

Filipowicz G. (2004), Zarządzanie kompetencjami zawodowymi, PWE, Warszawa.

7. Gratton L., Ghosal S. (2003), Inwestowanie w „osobisty kapitat ludzki”, „Zarządzanie na

8. Świecie", nr 11, s. 20-25.

9. Griffin R.W. (2017), Podstawy zarządzania organizacjami, Wydawnictwo Naukowe PWN, Warszawa.

10. http://pwszzamosc.pl/data/file_attachment/165-2849-planeta.pdf (dostęp: 04.10.2017).

11. https://hrwisdomkeeper.wordpress.com/2012/10/09/modelekompetencjiidefiniowaniekompe 12. tencjiworganizacji (dostęp: 09.10.2017).

13. Jabłońska-Wołoszyn M. (2003), Kompetencje w organizacji, „Personel i Zarządzanie”, nr 11, s. 12-15.

14. Jędrzejczyk W. (2013), Intuicja jako kompetencja menedżerska $w$ teorii i praktyce zarzqdzania przedsiębiorstwem, TNOiK „Dom Organizatora”, Torun.

15. Johnson G., Scholes K. (1999), Exploring Corporate Strategy, Prentice Hall Europe, London.

Krawczyk-Sokołowska I. (2008), Rola menedzera w przedsiębiorstwie innowacyjnym, [w:]

16. Krawczyk-Sokołowska I. (red.), Teoretyczne i praktyczne aspekty innowacji $w$ gospodarce polskiej, Sekcja Wydawnictw Wydziału Zarządzania Politechniki Częstochowskiej, Częstochowa, s. 145-155.

Krawczyk-Sokołowska I. (2012), Innowacyjność przedsiębiorstw i jej regionalne uwarunkowania, Wydawnictwo Politechniki Częstochowskiej, Częstochowa. 
Krzepicka A. (2015), Spoleczna odpowiedzialność przedsiębiorstwa, [w:] Bieliński J., Nogal-Mergel P. (red.), Zarzadzanie w przedsiębiorstwie i regionie. Nowe wyzwania, Wydział Zarządzania Uniwersytetu Gdańskiego, Sopot, s. 21-36.

Kubicka-Daab J. (2001), Człowiek z właściwościami. Zastosowanie modeli kompetencyjnych w zarządzaniu zasobami ludzkimi, „Personel”, nr 23, s. 24-27.

Kuc B.R., Paszkowski J. (2007), Organizacja - wartości - zarządzanie, [w:] Orechwa-Maliszewska E., Paszkowski J. (red.), Zarządzanie wartościa organizacji, Wydawnictwo Wyższej Szkoły Finansów i Zarządzania w Białymstoku, Białystok, s. 17-19.

Lee C., Lee K., Pennings M.J. (2001), Internal Capabilities, External Networks and Performance: A Study on Technology-Based Ventures, „Strategic Management Journal”, No. 22, s. 615-640. DOI: 10.1002/smj.181

Markus L.H., Cooper-Thomas H.D., Allpress K.N. (2005), Confounded by Competencies? An Evaluation of the Evaluation and Use of Competency Models, „New Zealand Journal of Psychology", Vol. 34, No. 2, s. 117-126.

Mintzberg H. (2013), Zarządzanie, Wolters Kluwer, Warszawa.

21. Oleksyn T. (1999), Zarządzanie kompetencjami w organizacji. Istota, cele, system, „Humanizacja Pracy - Zarządzanie Zasobami Ludzkimi”, nr 3, s. 7-28.

Pachura A., Nitkiewicz T., Kuraś M. (2016), Zmiana a sukces organizacji - porównawcze studium przypadku wybranych przedsiębiorstw, [w:] Jaki A., Kowalik M. (red.), Procesy restrukturyzacji wobec współczesnych przemian gospodarczych, Fundacja Uniwersytetu Ekonomicznego w Krakowie, Kraków, s. 29-40.

Penc J. (2007), Nowoczesne kierowanie ludźmi, wywieranie wplywu i współdziałanie w organizacji, Difin, Warszawa. Robbins S.P., DeCenzo D.A. (2002), Podstawy zarzadzania, PWE, Warszawa. Rogozińska-Pawełczyk A. (2006), Kompetencje w organizacji, „Acta Universitatis Lodziensis. Folia Oeconomica", nr 199, s. 99-120.

Rostowski T. (2002), Kompetencje jako jakość zarzadzania zasobami ludzkimi, [w:] Sajkiewicz A. (red.), Jakość zasobów firmy. Kultura, kompetencje, konkurencyjność, Poltext, Warszawa, s. 83-112.

Seroka-Stolka O. (2017), Uwarunkowania proaktywnego podejścia do proekologicznego rozwoju przedsiębiorstwa, Wydawnictwo Wydziału Zarządzania Politechniki Częstochowskiej, Częstochowa.

30. Skowron-Grabowska B. (2015), Innovation Business Activity of Companies, [w:] Brzozowska A., Kalinichenko A. (red.), Transformation Management of Economic at Rural Areas, Poltava State Agrarian Academy, Poltava, s. 111-119.

Skowron-Grabowska B., Łęgowik-Świącik S., Kowalska S., Stępień M. (2016), Instrumentarium sprawnego decydowania $w$ zarządzaniu przedsiębiorstwem - studium przypadku, [w:] Borowiecki R., Rojek T. (red.), Zarządzanie przedsiębiorstwem. Analiza wspótczesnych uwarunkowań, koncepcji, determinant, Fundacja Uniwersytetu Ekonomicznego w Krakowie, Kraków, s. 81-91.

33. Whiddett S., Hollyforde S. (2003), Modele kompetencyjne w zarządzaniu zasobami ludzki$m i$, Oficyna Ekonomiczna, Kraków.

Wood R., Payne T. (2006), Metody rekrutacji i selekcji pracowników oparte na kompetencjach, Oficyna Ekonomiczna, Kraków.

Ziółkowska B. (2013), Zarzadzanie procesami tworzenia wartości w przedsiębiorstwie. Perspektywa wirtualizacji, Wydawnictwo Politechniki Częstochowskiej, Częstochowa. 


\section{MANAGEMENT OF EMPLOYEE COMPETENCES FROM THE PERSPECTIVE OF ORGANIZATION DEVELOPMENT}

Abstract: Employee competences in modern reality contribute significantly to the success of an organization. Therefore, the article focuses on competences and their impact on organizations. An attempt was made to identify employee competences that determine the development and competitiveness of the organization in a decisive way and shape the company's image. It has been demonstrated that an appropriate approach to the development of employee competences can result in quality and efficiency of work. In the competence approach, the point of reference is the employee performing a particular job, not the job itself.

Keywords: competences, competency management, development 